\title{
Distant vs. Familiar Significant Others: Attitudes towards Absent Muslim Refugees and Extant Labor Migrants in Poland
}

\author{
Michał Buchowski
}

\begin{abstract}
Poles exhibit contrasting attitudes towards absent Muslim refugees and physically present Ukrainian labor immigrants. Both groups have been historically seen as "Significant Others," potentially perilous to the nation. Today, however, Muslims are rejected, while Ukrainians are accepted. This situation can be attributed to historical, ethnic, political, social, and economic factors, all of which are discussed here. The ethnic, linguistic, and religious superhomogeneity of Polish society affects the approach to the "culturally distant" Muslim migrants who were cynically rejected by the right-wing populist authorities during the 2015 refugee crisis. Economic necessity justifies the acceptance of the Ukrainians, who are perceived as culturally close. It is argued here that within the category of Significant Others, it is necessary to distinguish between Distant/Absent/Hostile and Familiar/Present/Tolerated Significant Others.
\end{abstract}

Keywords refugees, migration, Muslims, Ukrainians, Islamophobia, Significant Others

\section{Introduction}

In this article, I will interpret the contrasting attitudes of Poles and the Polish authorities with respect to two types of foreigner groups: (1) refugees, mostly Muslim "Significant Others," a group generally geographically distant and, in practice, absent from the country, and (2) labor immigrants, an increasingly present group of "Familiar Others." Significant Others "represent what the ingroup is not" (Triandafyllidou 2001, 33), typically "other nations or ethnic groups that are perceived to threaten the nation" (Triandafyllidou 1998, 594); they personify negative attributes rejected as unacceptable by a given group, to which these attributes presumably cannot be assigned, and for which they are viewed as inherently alien. Familiar Others, usually ethnic neighbors, though in 
certain contexts also functioning as detested Significant Others, are nevertheless not only territorially close, but also share some parts of history. There is an ongoing interaction with members of this group, and therefore they are perceived as culturally similar. Although the actual experience of Poles with these two social groups, i.e. Muslims and Ukrainians, is radically different-respectively, one is empirically absent and the second is physically present-their comparison is justified by the assumption that their discursively created "representations are social facts" which act as "strong and effective forces" (Rabinow 1986, 241) affecting the perception of various types of Others.

In order to elucidate these phenomena, I will provide data on the ethnoreligious composition of Poland's highly homogeneous society, then give a short account of the attitudes of Poles toward these Others as well as of indicative events in recent years ensuing from xenophobic stereotypes, especially those related to Muslim believers. It is striking how hostile standpoints are towards generalized "Muslims," whose presence in Polish society is negligible. The 'refugee crisis' of 2015 in Europe-deftly manipulated by populist politicians in the name of ensuring their nations' security and cultural integrity, or even their survivalengendered a 'phantom Islamophobia' rooted in historically shaped Orientalizing stereotypes. Despite a rise in racially tinted nationalism, perceptions of the much more numerous Ukrainian laborers are different from those of Muslims.

\section{Poland: A Superhomogeneous Country-Ethnically, Linguistically, and Religiously}

Steven Vertovec (2007) has argued that in recent decades many western and north-western European countries have become superdiverse as a result of their acceptance of immigrants. In contrast to these states, Poland may be called in ethnic, linguistic, and religious terms (even though not in several other aspects) a superhomogeneous country (Buchowski 2016, 53). According to the last census taken in 2011, out of 38.5 million citizens, 94.83 percent declared Polish nationality, and for 97.8 percent of them Polish was a language spoken at home. Those claiming dual (i.e. Polish and another) nationality numbered eight hundred and seventy-one thousand (2.7 percent), while only five hundred and ninety-six thousand (1.55 percent) declared a single nationality other than Polish. One should also keep in mind that for technical reasons-for instance open refusal or lack of answer (Gołata 2013,124) _for more than half a million people (1.35 percent) ethnicity was not determined (Wyniki 2012, 17-18; Struktura $2015,29)$. The state official statistical office summed up the situation thus: "The population with Polish national identification included altogether almost 37.394 million people, which is 97.1 percent of Poland's total inhabitants, while nonPoles comprised almost 1.468 million, i.e., 3.8 percent" (ibid., 30). ${ }^{1}$ It can be safely 
said that the ethnic landscape of the country's citizenry is indeed, and not only by European standards, highly homogeneous.

This homogeneity is a consequence of the postwar reconstruction of Poland, which involved enormous border changes, as a result of which Poland lost the eastern lands of its prewar polity at the expense of the Soviet Union and gained a smaller amount of territory from a defeated Germany; a population exchange with the Soviet Union in the east; and, as agreed upon in the Potsdam Treaty, the removal of ethnic Germans from what are today Poland's western, northwestern and north-eastern (former East Prussia) lands. Following war atrocities driven by a raging nationalist ideology, a homogeneous nation state appeared. It represented an ideal polity for the political forces in the region, one that would secure internal ethnic coherence and harmony (see Ther and Siljak 2001, esp. "Part I: Creating a Polish Nation State").

After the Polish People's Republic was established and population resettlement completed, the Iron Curtain's isolationist migratory regime limited border crossings to a minimum, especially during the Stalinist period (in practical terms, until 1956). Later, several liberalizations of laws on cross-border movements were enacted, leading to exit migration of Polish citizens to the West. Migration opportunities were used above all by ethnic Germans, thanks in large part to a 1975 agreement signed between Poland and the Federal Republic of Germany, as a result of which several hundred thousand Germans, the so-called Späteaussidlers, left Poland (see Schmidt 2009), but also by Jews, both in the first decade after World War II, and under coercion following an anti-Semitic campaign in 1968 (see Stola 2006). Later, Polish labor and political migrants also left the country. For instance, between 1960 and 1980 the number of those who chose to emigrate permanently amounted to five hundred thousand (on average, twenty-five thousand a year), rising to four hundred thousand in 1989 alone (see Stola 2010). The reigning "closed door" policy and poor economic standards meant that immigration to Poland under communism was nearly nonexistent. Exceptions included so-called Polish repatriates from the Soviet Union, who were allowed to move to their "homeland" during the period of political relaxation after 1956, and some international students from "befriended Third World countries" and Palestine who decided to stay in Poland after completing their studies, as well as some Vietnamese students and laborers in the 1970s. In general, since World War II, these combined processes, involving both the recurring emigration of minorities and curbed immigration, systematically furthered the homogenization of the population in Poland.

After the collapse of the ancien régime in 1989, Poles were granted the freedom to travel. After Poland's accession to the European Union (EU) on May 1, 2004, the number of migrants to the "old EU-countries" and other European Free Trade Association countries (Iceland, Lichtenstein, Norway, and Switzerland) increased significantly. The overall number of Polish citizens dwelling abroad at 
any given moment, both as permanent residents and as temporary or circular migrants, is calculated at the level of roughly 2.5 million, with 88 percent of them in Europe, and 83 percent in the EU alone (Kalwasiński 2019).

The situation with immigrants to Poland has also changed and evolved over the years. According to the census taken in 2011, only seventy-six thousand residents in Poland ( 0.2 percent of the population) were foreigners. This number did not reflect the reality on the ground. Even governmental agencies estimated that at that time the number should have been raised to three hundred and eighty thousand (1 percent) (Raport 2012, 96; Współpraca 2012, 9). Since 2011, when the census was conducted, things have changed a great deal. First, the number of immigrants to Poland has increased significantly. According to data from the Organization for Economic Co-operation and Development (OECD), the number of foreign-born people in Poland in 2017 amounted to six hundred and ninety-six thousand, which represents 1.8 percent of the total population. ${ }^{2}$ The war in the Donbas region and the occupation of Crimea brought about an economic crisis in Ukraine that led its citizens to seek job opportunities in more prosperous neighboring countries, such as the Czech Republic, Hungary, Slovakia, and Poland. The latter accepted the largest number of Ukrainians (see Jóźwiak and Piechowska 2017). Despite the fact that "due to the predominantly temporary character of the migration, it is difficult to estimate the exact number of Ukrainian migrants residing in Poland" (Jaroszewicz 2018, 5), estimates placed the number at nine hundred thousand at the end of 2017. The OECD has stated that by accepting 1.1 million temporary migrants-with a legal stay of up to twelve months-Poland was first in the world, ahead of even the United States with seven hundred thousand and Germany with four hundred thousand, in terms of the number of transitory migrants (Business Insider 2019). According to the most recent estimates of the National Bank of Poland, the number of Ukrainians has risen to 1.3 million, among which three hundred thousand have work permits (Gazeta Wyborcza 2019). It is worth mentioning that over fifty thousand Polish citizens have a declared affiliation with the Ukrainian minority. All these numbers add up to 3 percent of the population residing in the country at any given moment. However, this most recent wave of migration to Poland from the east-and one should keep in mind that it is in principle temporarydoes not substantially change the fact that in comparison to other immigrant countries in Europe, the number of nonethnic Poles in Poland is relatively low, and the country remains essentially ethnically homogeneous. ${ }^{3}$

The homogeneity of Polish society is also noticeable with regard to religious denomination. The 2011 census results are partial, since not all respondents are eager to answer questions regarded as personal (8.7 percent refused), and religious minority members are especially reluctant to do so. Among those answering, 96 percent declared that they were Roman Catholics (Struktura 2015, 94-98); only four hundred and ninety-three thousand (1.3 percent) claimed other 
denominations, with 2.4 percent stating that they were religiously indifferent or areligious. ${ }^{4}$ While these declarations reflected in many cases "cultural belonging," and Sunday mass participation has dropped below 40 percent (Annuarium Statisticum 2016, 14-18), five thousand one hundred people (0.013 percent of those answering) declared that they are Muslims in the census (Struktura 2015, 95). The number of Orthodox believers was over half a million, which made it the largest religious minority in Poland. Again, in relation to most other countries in the region, these numbers are patently low. ${ }^{5}$

\section{Muslims in Poland}

Official census data reporting that there are only five thousand Muslims living in Poland underestimate their number. It is estimated that there are actually between twenty thousand (Kubicki 2006) and forty thousand (Stryjewski 2011, 56). Still, this means that Muslims in Poland comprise at best 0.1 percent of the overall population. This small group is also internally differentiated (for a general overview see Pędziwiatr 2011a). One can distinguish here six subgroups: (1) Polish Tatars who settled in Polish territories as early as the 13th-14th centuries, and which are recognized as an ethnic minority by Polish law. According to the 2011 census, a total of 1,916 persons declared Tatar nationality, among which only 665 listed it exclusively (Ludność 2013, 261). Dispersed across the country, the Tatar community in Poland has its roots in north-east Poland, close to the Belarussian border. They are linguistically assimilated (Chazbijewicz 2010, 301) and in non-religious respects are often socially unmarked. The Islamic faith and its rituals serve as their cultural diacritics. (2) "Old immigrants," a group consisting of the descendants of several small waves of settlers between the 18 th century and World War II; these people are also largely integrated into mainstream society. (3) Graduates of Polish universities during the communist period and their offspring, mostly from Arab countries and Palestine (Pędziwiatr 2011b, 171-74). (4) Refugees and asylum seekers escaping wars in the former Yugoslavia in the 1990s and the prolonged conflicts in Afghanistan, Chechnya, and Syria (Marciniak 1997, 353-59). (5) Small investors, such as Turkish or North African entrepreneurs, often restaurant or bistro owners (see Adamowicz and Kochaniewicz 2012, 116-27; Nowaczek-Walczak 2012). Lastly, (6) a tiny group of local converts to Islam, largely ignored in analyses of Polish Muslims (exceptions: Boćkowski 2009, 43; Łojek-Magdziarz 2007).

The legal status and social perception of these groups vary. As mentioned earlier, Tatars are recognized as an ethnic minority as well as part of the nationwide society. They are subjected to the logic of hierarchical pluralism, a system of social relations admitting "diversity while making it clear which (ethnic/ religious) group is dominant and norm-defining" (Pasieka 2013, 58; 2015). In 
general, minorities are tolerated as long as they remain low-key in the public sphere and do not demand recognition in a manner that challenges the majority's unquestioned and unmarked domination. As an insignificant group numerically, Tatars are encompassed into the national imagery as proof of a now phantasmal "traditional Polish tolerance." However, there is no connection between the tolerance exercised in the period of the multiethnic and multireligious Polish Kingdom before its collapse in 1795 and today's attitudes and policies (Buchowski and Chlewińska 2012, 360). Those who settled in Poland during the communist period hold Polish citizenship, and many newcomers have a similar status or permanent residence permit.

One should keep in mind that since 1999, as a result of the two wars in Chechnya, eighty-six thousand Muslim war refugees have arrived in Poland. However, most of them have migrated further to western Europe and the Czech Republic or returned to the Russian Federation (Stryjewski 2011, 149-50). Between 2003 and 2014 alone, seventy-three thousand Russian citizens, mostly of Chechen ethnic background, applied for refugee status and found shelter in Poland (Stummer 2016). It is estimated that only three to five thousand (Pędziwiatr $2011 \mathrm{~b}, 173$ ) or seven to eight thousand (Zuchowicz 2015) of them decided to stay in the country. This migration wave did not breed Islamophobia. ${ }^{6}$

\section{Perceptions of Muslims by Poles}

The reception of war refugees from Chechnya was positive because, as some authors have explained, Poles have a "mostly negative attitude towards Russia" and the country had its "own 'experiences' with the USSR." This ignited solidarity with those suffering from Putin's cruel policy towards this rebellious nation (Stummer 2016). This fact outshone other, often negative, perceptions of Muslims which were bolstered by the September 11 attacks on the World Trade Center in New York City and several other assaults on civilian targets in Europe. This friendly attitude towards Chechens prevailed also despite general long-standing and widespread negative stereotyping of Muslims. As sociological surveys show, the word "Islam" evokes such associations as "terrorism," "war," "violence," "aggression," "fundamentalism," "Islamists," "Islamic radicals," and "fanaticism," but also "poverty and backwardness." Only 2 percent think more positively and connect Islam with "oriental or Arab culture" (Górak-Sosnowska 2006, 15960; Marek 2008, 38). In studies on attitudes towards other nationalities, Arabs, commonly concomitant with Muslims, have for years been consistently at the bottom of the list in terms of sympathy. For instance, in 2018, 65 percent of respondents disliked them, while 13 percent expressed positive sentiments. Next to them were Roma with 57 percent negative and 17 percent positive opinions (CBOS 2019, 2-3). Given the general absence of Muslims in Poland, this is 
indeed a case of "phantom Islamophobia" (Włoch 2009, 65), a "phenomenon of strong anti-Muslim sentiments in the absence of a significant Muslim minority" (Pędziwiatr 2015, 145).

In general, the Polish authorities have long been reluctant to accept refugees and asylum seekers. Since 1990 a mere four thousand applications for refugee status have been approved, which makes for an acceptance rate of just 2 percent. This reluctance regarding Others became conspicuous during and after the refugee crisis in 2015. In 2016, twelve thousand applications for refugee status were filed, mostly from Russia, and in the same year, just forty-four applications were approved (Pawłowska 2017).

In 2015, the right-wing, nationalist and populist ${ }^{7}$ Law and Justice Party (Prawo i Sprawiedliwość, PiS), in coalition with two smaller rightist parties, won national elections. Alongside nationalism, hostility towards refugees and Islamophobia became this political camp's trademarks. Migrant flows helped conservatives and traditionalists gain power-it was at least among the decisive factors that tipped the balance in their favor. Refugees have been presented by PiS not as victims of war or poverty, but as criminals. In a parliamentary speech just before the elections in 2015, Jarosław Kaczyński, the leader of this rightwing political grouping, proclaimed in post-truth fashion that fifty-four "sharia zones" where the state had no control existed in Sweden; citizens were afraid to hang the Swedish flag, and girls were fearful of wearing short skirts. In Italy, churches are supposedly used as toilets. Moreover, he claimed that immigrants brought cholera, dysentery, parasites, and protozoa. The Swedish embassy resolutely denied these statements based on fake news, but that did not stop their circulation in public discourse. The more liberal party then in power was attacked by Kaczyński for adopting a subservient stance toward the European Union when it agreed to accept more than seven thousand Syrian war refugees scheduled to be resettled from Greece and Italy (Buchowski 2017, 521).

After assuming power, the right-wing authorities quickly rejected this agreement. The minister of interior affairs insisted that the new government's unyielding anti-immigrant policy guaranteed security to Poles, and therefore it adamantly refused to accept refugees relocated from the Mediterranean. Acting against international and domestic law, border guards also denied asylum seekers entry onto Polish territory, including Chechens and Tajiks escaping Presidents Kadyrov and Rahmon's cruel dictatorships (Cieślewska and Szczepanik 2016). Jarosław Gowin, the deputy prime minister and minister of science and higher education, despite his declared religious piety, criticized Pope Francis for his refugee-friendly approach. Gowin, like many conservative Catholic Church officials in Poland, was concerned about the possible negative impact of "religious Aliens" on Polish society. At one point he said: "We should receive refugees, but they should not be Muslim believers. They do not assimilate" (cited from Legut and Pędziwiatr 2018,47). Statements by top politicians and several bishops 
paved the way for anti-Muslim slogans in the public sphere to be expressed freely by "true patriots" during street demonstrations, soccer games, and on social media. This was done in the name of freedom of speech unrestricted by a "blackmailing political correctness" (Konopka 2019, 46). Charges against culprits propagating ethnically, racially, or religiously motivated hate were often dismissed in the courts as unsubstantiated (Buchowski 2016, 60-61; 2017, 521). Several scholars documented this upsurge in anti-refugee, anti-Muslim, nationalist, and xenophobic discourse (Krzyżanowski 2016; Konopka 2019).

The positions of populist politicians, widely aired in the PiS-controlled public media, have brought about unprecedented changes in attitude in Poland towards refugees. Research results illustrate this process. Bart Bachman has written that "data from the European Social Survey between 2002 and 2012 show that Poles consistently held some of the most pro-immigration views in Europe, expressing similar views towards refugees and asylum seekers... Poles agreed or strongly agreed that their government 'should be generous judging applications for refugee status." With 63.4 percent having a positive attitude towards them, "it was a more positive response than voiced by Swedes (60.3 percent) and Germans (38.8 percent)" (Bachman 2016). In mid-2015, 63.9 percent of Poles were still ready to accept refugees from European countries and 52 percent from nonEuropean ones (Andriejuk 2015, 11). Opinion polls attest that the number of those rejecting refugees from the Middle East and Africa in Poland rose from 30 percent in 2013 to 48 percent in September 2015 and again to 74 percent in April 2017, and that those ready to receive and allow refugees to settle in Poland ranged between 2 and 5 percent (CBOS 2017, 2). A decisive majority of Poles, ranging between 55 and 76 percent, approve violent solutions towards asylum seekers (Świderska, Winiewski, and Hansen 2016, 7). The findings of Pew researchers show that 66 percent of Poles had an unfavorable view of Muslims, which ranks them third among European nations, just after Hungarians (72 percent) and Italians (69 percent), and before Greeks (65 percent) and Spaniards (50 percent) (Wike, Stokes, and Simmons 2016).

These negative approaches often translate into violent acts. Hate speech is proliferating in Poland. The number of legal investigations of ethnically and racially motivated verbal (mostly online) or physical violence increased from 835 in 2013 to 1,548 in 2015. Successive "Brown Books" (Brunatna Księga), which report cases of racially motivated crimes, compiled each year by the Never Again Association (see Kornak, Tatar, and Pankowski 2016), make us aware of the extent of this phenomenon. Racially inspired physical violence is being registered much more frequently than in the past. In just the four days during and after New Year's Eve 2017, there were reports of two drunk youths in Ełk (north-east Poland) who yelled slurs at the owners of a kebab shop, who came from the Maghreb, and attempted to steal bottles of Coke. The ensuing brawl ended with the death of one of the offenders, resulting in riots during which the shop was demolished. In 
Lubin (south-west), vandals destroyed a kebab shop owned by an Indian man and spray-painted it with vulgar anti-Muslim texts. Another kebab shop operated by a Kurdish man was attacked in Wrocław (south-west), an Indian restaurant was damaged in Szczecin (north-west), a Bengali man was beaten in Legnica (southwest), and a Pakistani assaulted in Ozorków (central Poland). Thus, in this short period, six xenophobic attacks were reported across the country (see Buchowski 2017, 519-20). Racially motivated and anti-Muslim violence has continued following the refugee crisis (Pędziwiatr 2017).

\section{Discussion: Reasons for the Rising Tide of Xenophobia}

That the range and extent of the changes relate to something that I call the "xenophobic turn" can hardly be denied. A comprehensive understanding of this trend requires thorough empirical research that will juxtapose diachronic and synchronic perspectives as well as pay attention to such factors as class belonging, education, religious affiliation, political preferences, and regional differences. It should also address the differences in declarations towards and actual relations with Others in everyday life. Here, on the basis of the data and facts reported above, I propose some preliminary answers to only some questions: Why has Polish society proven to be so vulnerable to xenophobic ideologies? What has caused this increase in intolerant, prejudiced, and particularly anti-Muslim attitudes in the last five years? What causes such a difference in standpoints towards victims of conflicts coming from various parts of the world and at different periods, in our case Chechnya and Syria? What triggered such a sweeping change in attitudes towards refugees in such a short time span? And finally, why are refugees, perceived as tantamount to Muslims, rejected, while Ukrainian labor migrants are accepted?

\section{Historical Homogeneity}

First, at the end of World War II in 1945, the population of the country was homogenized in terms of both its ethnic and religious composition. For more than four decades, Poland was also relatively isolated. Emigration was limited but continued, and to a large extent comprised ethnic or religious minorities such as Germans (after postwar ethnic cleansing, Späteaussidlers from the 1970s and 1980s), Ukrainians (after World War II and 1956), and Jews (in the 1940s and1950s, and in 1968). Immigration to the country was virtually non-existent. The conjoined emigration of minorities and dearth of new immigrants not only reinforced the existing "monoculture," but also caused further ethnic and religious uniformization of the society. This kind of homogeneity became the norm, an "obvious obviousness," and on various occasions was actually praised. Superhomogeneity was taken for granted. It coincided with the conception of 
an ideal nation state in which ethnic and political borders coincided, which in result, and in contrast to the former Yugoslavia or Ukraine, the three postSoviet Baltic states or Romania, "helped" to avoid ethnic conflicts during the turbulent historical transformations after 1989. For nationals in a monoethnic state, Others lived "somewhere out there," as hypothetical beings. Several nonEuropean, "exotic" groups were, on the one hand, represented in a Eurocentric, patronizing perspective, while on the other hand, in official propaganda they were presented as people struggling with colonization and discrimination and in need of assistance. However, everyday encounters with foreigners, except for incidental and transient contacts with tourists and as tourists, were not an issue. Unquestioned national unity was not seen as endangered. In this mental milieu, refugees were perceived rather as sufferers of conflicts than as a potential threat to the nation. Their fate inspired compassion informed by images related to the Polish nation's own tragic history of persecution and forced migrations. Moreover, the image of refugees was abstract, as they were practically nonexistent. In this setting, Muslim Chechens were also not associated in the first place with Islam, but instead with the brutal oppression they experienced by the eternally hostile, as many Poles think, Soviet/Russian empire.

\section{Numerical Marginality of the Others: Between Tolerance and Antipathy}

Second, in modern Polish history Muslims have always been numerically marginal. Their presence has been negligible not only in the post-World War II period. Despite the negative connotations the words "Islam" and "Muslims" have had for people in the present century as well as the antipathy expressed in opinion polls towards "Arabs," Muslim communities which have been settled in the country for centuries or decades have not been subjected to exceptional public odium. Tatars have been seen as part of the national history and local folklore, tangible proof of the mythical Polish tolerance. Since the political leaders who grasped power in 2015 have stubbornly refused to accept any refugees in the relocation program for people living in the EU's refugee camps, the number of Muslims has not changed since the critical year of the refugee crisis. However, a long-established resentment shown towards Muslims has not disappeared, existing somehow quiescently. Awakened in 2015, it stopped being "merely" a dormant case of phantom Islamophobia in which an antipathy towards "Muslims without Muslims" was shown. The compassion expressed towards generic refugees, among them Muslims, transformed into a rapid growth in hostility towards Muslim refugees escaping war in Syria.

\section{Distant/Absent/Hostile Significant Others}

Third, what was the reason for this conspicuous rise in verbal aggression and sometimes physical abuse? The right-wing populist political camp did not justify its rejection of refugees merely on the basis of an inadequate infrastructure for 
their reception. Above all, it chose and developed it as a deliberate discursive strategy; a "governmentality" based on the stigmatization and securitization of Muslims (see Kaya 2011; Bobako 2017). Such a policy had several cornerstones. Above all, this was fear of the Other, which was relatively easy to stir up in Poland's superhomogeneous society. The words of Kaczyński cited above exemplify this scheme. In the case discussed, "the threatening Other" is created as a distant, Oriental, exotic Other. Distant and at the same time Absent Others are represented as endangering "us," even if only in theory, both physically, by bringing unknown diseases, and culturally, by altering our customs and even dress code, and colonizing our spaces, e.g., turning "sacred for us Poles" churches into toilets. This strategy paid off thanks to existing - though for years rather passive, if not dormant-stereotypes about "Arabs" which, in a longue durée historical perspective have their roots in collective images about Muslim "infidels" and the role Poles played in history as defenders of Christian Europe, in the mythology of Poland as an Antemurale Christianitatis (see Davies 2005, 125-55, chapter 6: "Antemurale"), a bulwark of Christianity. This mythology implies a "frontier myth of Orientalism" (Gingrich 1998, 104), not uncommon in Austria, Hungary, and in some Balkan regions, one that was skillfully reinvigorated by populist authorities and their media outlets. It divides the world into "us" and "them," utilizing a process known as "double negation" in which, in the first move, and as mentioned at the beginning, the Others are construed as people embodying all the negative attributes of "us," and, in the second move, "we" are imagined as the ultimate opposite of the negative self-image. The refugees, now in public discourse synonymous with Muslims/Arabs, have started to stand "for that which is disliked, detested, abhorred and hated" (Schiffauer 2013, 106) -in brief, they are Significant Others. In typecasting Muslims as a renewed danger, the motif of Islamic terrorism has been conjured up in a country that has not witnessed any terrorist attack within its borders. This succeeded thanks to an intellectual operation known as pars pro toto. Terrorist attacks carried out by Muslim extremists have been attributed to all Muslims. Populist authorities have artfully frightened their fellow citizens, and in their posturing and claims to ensure security, they have rigidified their stand towards any non-labor immigrants and made this a token of their unequivocal policy towards refugees/ Muslims. This was used as an argument even in local elections in 2018. On a business trip on September 8 through the medium-sized city of Leszno, I documented a PiS banner on a roadside fence: "We keep our promises: Defending Poland against Islamization."

Islamophobia is entangled in nationalist ideas. In this version of nationalism, the nation is reified. This implies that imports of alien people, cultures, habits, customs, and religious ideas pose a threat to its very existence and infringe upon its imagined unspoiled shape. Significant Others and at the same time Distant Others are made Hostile Others. These culturally alien people, who do not fit into 
our culture, represent at the same time a belligerent religion, always inimical to "our" Christian faith and traditions.

\section{Familiar Significant Others}

Fourth, within this framework, Ukrainian labor immigrants are perceived differently, despite the fact that historical relations with them in the 20th century are presented by nationalists as full of atrocities and unsettled conflicts. In that sense, in some contexts and for some people, they feature as Significant Others. However, although the attitude towards them is not very favorable, 41 percent express antipathy and 31 percent declare sympathy (CBOS 2019, 3), and xenophobic incidents involving Ukrainians are not uncommon, nothing similar to Islamophobia can be witnessed. Particularly in the rhetoric of politicians, economists, and the media, the justifications for their presence are pragmatic, even cynical. The migration of two and a half million Poles to more affluent countries in Europe has caused shortages in the domestic labor force. Letting in Ukrainians is meant to fill a gap in this market. The opinions of Piotr Bujak, an economic expert, are typical in this respect. He admits ingenuously that Ukrainian workers come from "a country which is geographically and culturally close. Ukrainians very easily adapt in Poland, they learn the language quickly, and this helps alleviate the social tensions related to immigration observable in other countries, and also allows for a swift attainment of positive economic effects." He claims there are no reasons to complain about Poland's immigration policy, which does not "encourage people to stay for a longer period or settle in Poland. Our approach to immigration helped us to achieve so-called effective immigration, people determined to work and whose workplace is often assured at the moment of their arrival, and this helps avoid migration-related problems known in other countries" (Business Insider 2019). Avoiding problems caused by refugees is emphasized twice in this twofold argument. First, unlike Muslims who "do not assimilate," as the minister of higher education cited above thinks, Ukrainians do assimilate. By assimilating they do not endanger the nation's essential character, especially since they are Christians and their language is similar to Polish. They are not Distant Others. In that sense, they are acceptable because of their culturalreligious proximity and invisibility. Second, accepting Ukrainians facilitates economic growth and thus they actually help us to maintain the nation's existence and its prosperity. Temporary permits should make it clear that their presence is not expected to be permanent and they are encouraged to leave after their contracts are completed. In contrast to Muslim refugees, who were depicted as a threat to the nation and kept away as invaders, Ukrainians are presented as useful transitory workers. This premise, and promise, placates the public. 


\section{Conclusions}

The above discussion leads us to a more general conclusion regarding the concept of Significant Others. In principle, Anna Triandafyllidou (2001) limits its application to ethnic and/or national groups. I claim that it should be extended to certain religious groups for at least three reasons: (1) the perception of Muslims is closely related to nationalism and collective self-representation, often intertwined with religious denomination, and has become conspicuous not only among Polish nationalists, but also European nationalists and right-wing populists (see Brubaker 2017); (2) Muslims, as shown above, are in fact perceived often in quasi-ethnic terms as "Arabs," and because ordinary people do not deliberate over such categorical distinctions, these categories remain frequently blurred; and, (3) the mechanisms involved in making Significant (ethnic) Others and Significant (religious) Others are very similar.

Moreover, some distinctions within the category of Significant Others should be made. In Triandafyllidou's $(2001,34)$ words, Significant Others are "groups that share common cultural, ethnic or territorial features with the nation" and as a rule are neighbors. Ukrainians in relation to Poles fully meet this standard. They are also not seen as a threat to identity. At the same time, "dissimilar outgroups are already distinctive from the ingroup" (ibid., 34), and there is no need to differentiate oneself from them. In European countries that have accepted immigrants for decades, Muslims have become relevant internal Significant Others posing a threat to identity "from within." However, in the Polish case they are Distant, and in fact Absent and Unknown Significant Others who do not share much with "us," but are nevertheless perceived as relevant external agents threatening Polish identity. Therefore, I think that cultural similarity and territorial proximity are not decisive for a group to be perceived as Significant Others. If we accept this, then a distinction into "Distant" and "Familiar" Significant Others is justified.

\section{Notes}

1. The $1,468,000$ people claiming "non-Polish" identity comprised those declaring a nationality other than Polish or a dual nationality that could include Polish.

2. Organization for Economic Co-operation and Development (OECD). OECD Databases on Migration. https://www1.compareyourcountry.org/migration/en/1/all/ default (accessed January 14, 2020).

3. For instance, in Luxemburg 48 percent of the population are foreigners, in Switzerland 28 percent. Over 10 percent of the population is foreign-born in Cyprus, Austria, Estonia, Malta, Latvia, Belgium, Ireland, and Germany (see Eurostat, migr_pop3ctb); in the case of Latvia and Estonia, they are mostly post-Soviet Russian residents who have not obtained citizenship in the respective states. Data vary according to how statistics are "calibrated," 
but the overall number of immigrants of various statuses-temporary, permanent, labor, intra-European, and extra-European-is increasing systematically. In 2017 alone, 4.4 million people migrated in the EU, and among them 2.4 million were immigrants from outside the EU countries (see Eurostat 2019).

4. They are so, even if one takes into account the 2018 International Religious Freedom Report, which provides different numbers-with 86 and 91.6 percent identifying as Roman Catholics (U.S. Department of State 2018).

5. There are 25.8 million Muslims living in Europe, which is on average 4.9 percent of the total population. However, these numbers vary from country to country; for instance, in Bulgaria the number is 11 percent, in France 8.8 percent, in Sweden 8.1 percent, in Austria 6.9 percent, in the UK 6.3 percent, and in Switzerland 6.1 percent (Pew Research Center 2017); in Bulgaria most of these Muslims are historical minorities of Turks and Bulgarian-speaking Pomaks. It should be added that in Europe beyond the EU borders, 70 percent of the 3.4 million citizens in Albania are Muslims, or rather "people of Muslim origin" (Lederer 1994, 331), in Kosovo 93 percent (Ghaffar 2015, 159), ca.15-17 percent in Montenegro (Dimitrovova 2001, 95), 40 percent in Bosnia and Herzegovina, and 25-30 percent in Macedonia (Barisic 2007, 2-7). Altogether, eight million Muslims live in the Balkans (ibid., 1).

6. I do not engage in a complex discussion of the meaning of this concept. For the purpose of this article, the definition given in a recent Runnymede Report is sufficiently operational: "Islamophobia is any distinction, exclusion or restriction towards, or preference against, Muslims (or those perceived to be Muslims) that has the purpose or effect of nullifying or impairing the recognition, enjoyment or exercise, on an equal footing, of human rights and fundamental freedoms in the political, economic, social, cultural or any other field of public life" (Olahi and Khan 2017, 7).

7. Again, I do not intend to discuss the complex issue of populism in detail. It may simply be understood here as a concept that "in postmillennial politics, typically refers to right populism, which is characterized by emotionally-charged political appeals to addressing crises through neonationalism, masculinism, Othering, bordering, xenophobia, sexism, racism, phantasmatic ethnic golden-ageism, a disregard for liberal democratic norms, and so forth" (Gagnon et al. 2018, vi).

\section{References}

Adamowicz, Anna, and Agata Kochaniewicz. 2012. "Pracownicy branży gastronomicznej" [Workers in gastronomy]. In Migracje a heterogeniczność kulturowa. Na podstawie badań w Poznaniu [Migration and Cultural Heterogeneity], eds. Michał Buchowski and Jacek Schmidt. Poznań: Wydawnictwo Nauka i Innowacja, 116-27.

Andriejuk, Katarzyna. 2015. "Postawy wobec imigrantów w świetle wyników Europejskiego Sondażu Społecznego 2014-2015. Polska na tle Europy” [Attitudes towards migrants in the view of the European Social Survey results 2014-2015. Poland compared to Europe]. Polish Academy of Sciences, Institute of Philosophy and Sociology, European Studies Unit, Working Paper no. 2. Warszawa: IFiS PAN.

Annuarium Statisticum. 2016. Annuarium Statisticum Ecclesiae in Polonia AD 2016. (Annual Statistical Yearbook of the Church in Poland for 2016). Warszawa: Instytut Statystyki 
Kościoła Katolickiego SAC. http://iskk.pl/images/stories/Instytut/dokumenty/ AnnuariumStatisticum2016.pdf (accessed December 15, 2019).

Bachman, Bart. 2016. "Diminishing Solidarity: Polish Attitudes toward the European Migration and Refugee Crisis." Migration Policy Institute, 16 June. http://www. migrationpolicy.org/article/diminishing-solidarity-polish-attitudes-towardeuropean-migration-and-refugee-crisis (accessed December 20, 2019).

Barisic, Srdjan. 2007. "Muslims in the Balkans: Problems of (Re)Institutionalization and Transformation of Identity." In Islam at the Balkans in the Past, Today and Future, eds. Dragoljub Đorđević, Dragan Todorović, and Ljubiša Mitrović. Niš: YSSSR, 1-15.

Bobako, Monika. 2017. Islamofobia jako technologia władzy. Studium z antropologii politycznej [Islamophobia as a Technology of Power. A Study from Political Anthropology]. Kraków: Universitas.

Boćkowski, Daniel. 2009. "Between the East and the West: The Penetration of Contemporary Islam into Poland." Limes 2 (1): 39-47.

Brubaker, Rogers. 2017. "Between Nationalism and Civilizationism: The European Populist Movement in Comparative Perspective." Ethnic and Racial Studies 40 (8): 1191-226.

Buchowski, Michał. 2016. "Making Anthropology Matter in the Heyday of Islamophobia and the 'Refugee Crisis': The Case of Poland." Český lid 103: 51-67.

Buchowski, Michał. 2017. "A New Tide of Racism, Xenophobia, and Islamophobia in Europe: Polish Anthropologists Swim against the Current." American Anthropologist 119 (3): 519-23.

Buchowski, Michal, and Katarzyna Chlewińska. 2012. "Poland." In Addressing the Issue of Tolerance in Europe: A Comparative Overview of 16 Countries, eds. Ricard ZapataBarrera and Anna Triandafyllidou. Barcelona: CIDOB, 345-70.

Business Insider. 2019. "Zaskakujące dane OECD. Polska liderem pod względem migracji zarobkowej na świecie. Wyprzedziliśmy Niemcy i USA" [Surprising OECD data. Poland is a world's leader in labor migration. We have surpassed Germany and the US]. September 28. https://businessinsider.com.pl/twoje-pieniadze/praca/migracjazarobkowa-w-polsce-dane-oecd/3p5wp5g (accessed December 8, 2019).

CBOS (Centrum Badania Opinii Społecznej, Public Opinion Research Center). 2017. "Komunikat z Badań Nr 44/2017: Stosunek do przyjmowania cudzoziemców" [Research report no. 44/2017: An attitude towards receiving foreigners]. Warszawa: Centrum Badania Opinii Społecznej.

CBOS (Centrum Badania Opinii Społecznej, Public Opinion Research Center). 2019. “Polish Public Opinion (2/2019).” Warszawa: Centrum Badania Opinii Społecznej. https://www.cbos.pl/PL/publikacje/public_opinion/2019/02_2019.pdf (accessed December 12, 2019).

Chazbijewicz, Selim. 2010. “Tatarzy” [Tatars]. In Mniejszości narodowe i etniczne w Polsce po II wojnie światowej [National and Ethnic Minorities in Poland after World War II], eds. Stefan Dudra and Bernadetta Nitschke. Kraków: Nomos, 288-304.

Cieślewska, Anna, and Marta Szczepanik. 2016. "Odepchnięci z granicy” [Trusted back from the border]. Tygodnik Powszechny, September 11.

Davies, Norman. 2005. God's Playground A History of Poland: Volume 1: The Origins to 1795. Oxford: Oxford University Press.

Dimitrovova, Bohdana. 2001. "Bosniak or Muslim? Dilemma of One Nation with Two Names." Southeast European Politics 2 (2): 94-108. 
Eurostat. 2019. "Migration and Migrant Population Statistics. Statistics Explained." https:// ec.europa.eu/eurostat/statistics-explained/pdfscache/1275.pdf (accessed December 22, 2019).

Gagnon, Jean-Paul, Emily Beausoleil, Kyong-Min Son, Cleve Arguelles, Pierrick Chalaye, and Callum N. Johnston. 2018. "Editorial. What Is Populism? Who Is the Populist?" Democratic Theory 5 (2): vi-xxvi.

Gazeta Wyborcza. 2019. "W Polsce zabraknie rąk do pracy. Jeszcze nigdy tylu Ukraińców nie deklarowało chęci wyjazdu" [Poland will face a shortage of labor force. Never so many Ukrainians declared a will to leave]. December 5. http://next.gazeta.pl/next/ 7,151003,25482405,polsce-zabraknie-rak-do-pracy-niemcy-otwieraja-rynek-polowa. html (accessed December 6, 2019).

Ghaffar, Abdul. 2015. "Muslim Population of the Republic of Macedonia: A Demographic Profile." Balkan Social Science Review 6: 155-201.

Gingrich, Andre. 1998. "Frontier Myths of Orientalism: The Muslim World in Public and Popular Cultures of Central Europe." In Mediterranean Ethnological Summer School, vol. 2, eds. Bojan Baskar and Borut Brumen. Ljubljana: Inštitut za multikulturne raziskave, 99-127.

Gołata, Katarzyna. 2013. “Metodologia powszechnego spisu ludności i mieszkań w 2011 roku w zakresie pytań etnicznych" [Methodology of 2011 population and housing census in the field of ethnic questions]. Studia Demograficzne 1(163): 97-133.

Górak-Sosnowska, Katarzyna. 2006. "Co wiemy o islamie? Polacy wobec islamu i muzułmanów" [What do we know about Islam? Poles' attitudes towards Islam and Muslims]. Teofil. Pismo Kolegium Filozoficzno-Teologicznego Dominikanów 2: 149-64.

Jaroszewicz, Marta. 2018. Migration from Ukraine to Poland. The Trend Stabilizes. Warsaw: Center for Eastern Studies.

Jóźwiak, Ignacy, and Marta Piechowska. 2017. "Crisis Driven Mobility between Ukraine and Poland. What Does Available Data (not) Tell Us?” CMR Working Papers 99/157. Warsaw: Center of Migration Studies.

Kalwasiński, Maciej. 2019. "Maleje liczba polskich emigrantów. Polacy opuszczają Wielką Brytanię" [Number of Polish migrants is decreasing. Poles leave the United Kingdom]. Bankier.pl, November 15. https://www.bankier.pl/wiadomosc/Maleje-liczba-polskichemigrantow-Polacy-opuszczaja-Wielka-Brytanie-7773079.html (accessed December $15,2019)$.

Kaya, Ayhan. 2011. "Islamophobia as a Form of Governmentality: Unbearable Weightiness of the Politics of Fear." Willy Brandt Series of Working Papers in International Migration and Ethnic Relations, 1/11. Malmö: Malmö Institute for Studies of Migration, Diversity and Welfare (MIM).

Konopka, Adam. 2019. “'Us' and 'Them' in the Language of Conservative Islamophobia: Referential and Predicational Strategies in Polish Right-Wing Discourse on the Migration Crisis in 2015." Studia Humanistyczne 18 (1): 33-51.

Kornak, Marcin, Anna Tatar, and Rafał Pankowski. 2016. Katalog wypadków - Brunatna Księga 2014-2016 [Catalogue of incidents - Brown Book]. Warszawa: Nidy więcej.

Krzyżanowski, Michał. 2016. "Discursive Shifts in Ethno-Nationalist Politics: On Politicization and Mediatization of the 'Refugee Crisis' in Poland." Journal of Immigrant and Refugee Studies 16 (1-2): 76-96.

Kubicki, Paweł. 2006. “Kim są polscy muzułmanie?” [Who are Polish Muslims?] Teofil. 
Pismo Kolegium Filozoficzno-Teologicznego Dominikanów 2: 137-48.

Lederer, Gyorgi. 1994. “Muslims in Albania.” Central Asian Survey 13 (3): 331-59.

Legut, Agnieszka, and Konrad Pędziwiatr. 2018. "Sekurytyzacja migracji w polityce polskiej a zmiana postaw Polaków wobec uchodźców” [Securitization of migration in the Polish politics and change of Poles' attitudes towards refugees]. In Sami swoi? Wielokulturowość we wspótczesnej Europie [Just Our Folks? Mutliculturalism in Contemporary Europe], ed. Romuald Jończy. Gliwice-Opole: Dom Współpracy Polsko-Niemieckiej, 41-51.

Łojek-Magdziarz. 2007. "New Islam in Poland-Polish Converts." ORMA. Revistă de studii etnologice şi historico-religioase 6: 55-62.

Ludność. 2013. Ludność. Stan i struktura demograficzno-społeczna. Narodowy Spis Powszechny Ludności i Mieszkań 2011 [Population. Status and Socio-demographic Structure. National Census of Population and Housing]. Warszawa: Główny Urząd Statystyczny.

Marciniak, Tomasz. 1997. "A Survey of Muslim Minorities in Poland." Journal of Muslim Minority Affairs 17 (2): 353-59.

Marek, Agata. 2008. "Dlaczego boimy się islamu?” [Why we fear Islam?]. In Muzutmanie i uchodźcy w polskim społeczeństwie [Muslims and Refugees in the Polish Society], eds. Agnieszka Kosowicz and Agata Marek. Warszawa: Stowarzyszenie 'Vox Humana,' 37 41.

Nowaczek-Walczak, Magdalena. 2012. “The World of Kebab: Arabs and Gastronomy in Warsaw." In Muslims in Poland and Central Europe: Widening the European Discourse on Islam, ed. Katarzyna Górak-Sosnowska. Warsaw: University of Warsaw, Faculty of Oriental Studies, 108-25.

Olahi, Farah, and Omar Khan. 2017. "Introduction: What Is Islamophobia?" In Islamophobia: Still a Challenge to All of Us, eds. Farah Olahi and Omar Khan. London: Runnymede, 5-12.

Pasieka, Agnieszka. 2013. “How Pluralism Becomes Hierarchical.” Sprawy Narodowościowe 43: 53-73.

Pasieka, Agnieszka. 2015. Hierarchy and Pluralism: Living Religious Difference in Catholic Poland. Basingstoke: Palgrave.

Pawłowska, Danuta. 2017. "Ilu uchodźców znalazło w Polsce schronienie?" [How many refugees found refuge in Poland]. BiQDATA, February 2. http://biqdata.wyborcza.pl/ ilu-uchodzcow-znalazlo-w-polsce-schronienie (accessed December 23, 2019).

Pędziwiatr, Konrad. 2011a. "Muslims in Contemporary Poland.” In Muslims in Visegrad Countries, ed. Jaroslav Bureš. Prague: Anna Lindh Foundation and Visegrad Fund, 10-24.

Pędziwiatr, Konrad. 2011b. “The Established and Newcomers' in Islam in Poland or the Intergroup Relations within the Polish Muslim Community." In Muslims in Poland and Central Europe: Widening the European Discourse on Islam, ed. Katarzyna GórakSosnowska. Warsaw: University of Warsaw, Faculty of Oriental Studies, 169-82.

Pędziwiatr, Konrad. 2015. "Islamophobia as a New Manifestation of Polish Fears and Anxieties." In Nations and Stereotypes Twenty-Five Years After: New Borders, New Horizons, eds. Roman Kusek, Janusz Purchla, and Joanna Santera-Szeliga. Kraków: International Cultural Centre, 132-50.

Pędziwiatr, Konrad. 2017. “Islamophobia in Poland: National Report 2016.” In European Islamophobia Report 2016, eds. Enes Bayrakli and Farid Hafez. Istanbul: SETA. 
Pew Research Center. 2017. “Europe’s Growing Muslim Population,” November 29. https:// www.pewforum.org/2017/11/29/europes-growing-muslim-population (accessed December 29, 2019).

Rabinow, Paul. 1986. "Representations Are Social Facts: Modernity and Post-Modernity in Anthropology." In Writing Culture: The Poetics and Politics of Ethnography, eds. James Clifford and George E. Marcus. Berkeley: University of California Press, 234-61.

Raport. 2012. Raport z wyników. Narodowy Spis Powszechny Ludności i Mieszkań [Report from Results: National Population and Housing Census]. Warszawa: Główny Urząd Statystyczny.

Schiffauer, W. 2013. "The Logics of Toleration: Outline for a Comparative Approach to the Study of Tolerance." In Tolerance, Intolerance and Respect: Hard to Accept? eds. John Dobbernack and Tariq Modood. Basingstoke: Palgrave Macmillan, 103-26.

Schmidt, Jacek. 2009. Nowe tożsamości $w$ czasach transformacji europejskich. Imigranci $z$ Polski w Niemczech [New Identities in the Period of European Transformation. Immigrants from Poland in Germany]. Poznań: Wydawnictwo News-Witold Nowak.

Stola, Dariusz. 2006. "Anti-Zionism as a Multipurpose Policy Instrument: The Anti-Zionist Campaign in Poland, 1967-1968." Journal of Israeli History 25 (1): 175-201.

Stola, Dariusz. 2010. Kraj bez wyjścia? Migracje z Polski 1949-1989 [A Country with No Way Out? Migration from Poland, 1949-1989]. Warsaw: Instytut Pamięci Narodowej.

Struktura. 2015. Struktura narodowo-etniczna, językowa i wyznaniowa lundości Polski [Ethno-religious, Linguistic and Denominational Structure of the Polish Population]. Warszawa: Główny Urząd Statystyczny. https://stat.gov.pl/files/gfx/portalinformacyjny/ pl/defaultaktualnosci/5670/22/1/1/struktura_narodowo-etniczna.pdf (accessed December 13, 2019).

Stryjewski, Radosław. 2011. Integracja społeczna i gospodarcza imigrantów wyznania muzutmańskiego w Polsce. Raport $z$ badań [Social and Economic Integration of Immigrants of Muslim Origin in Poland. A Research Report]. Warszawa: Fundacja "Ocalenie."

Stummer, Krisztián. 2016. "Forgotten Refugees: Chechen Asylum Seekers in Poland." Krytyka Polityczna and European Alternatives. http://politicalcritique.org/cee/poland/ 2016/forgotten-refugees-chechen-asylum-seekers-in-poland/ (accessed December 30, 2019).

Świderska, Aleksandra, Mikołaj Winiewski, and Karolina Hansen. 2016. Przemoc jako rozwiązanie? Napływ uchodźców w opiniach Polaków [Violence as a Solution? Refugees Arrival in the Opinions of Poles]. Warszawa: Centrum Badań nad Uprzedzeniami.

Ther, Philippe, and Anna Siljak, eds. 2001. Redrawing Nations: Ethnic Cleansing in EastCentral Europe 1944-1948. Lanham, MD: Rowman and Littlefield.

Triandafyllidou, Anna. 1998. "National Identity and the 'Other." Ethnic and Racial Studies 21 (4): 593-612.

Triandafyllidou, Anna. 2001. Immigrants and National Identity in Europe. London: Routledge.

U.S. Department of State. 2018. "International Religious Freedom Report." United States Department of State, Bureau of Democracy, Human Rights, and Labor. https:// pl.usembassy.gov/wp-content/uploads/sites/23/religious_report_2018.pdf (accessed December 30, 2019).

Vertovec, Steven. 2007. “Super-diversity and Its Implications.” Ethnic and Racial Studies 30 
(6): 1024-54.

Włoch, Renata. 2009. "Islam in Poland: Between Ethnicity and Universal Umma." International Journal of Sociology 39 (3): 58-67.

Wike, Richard, Bruce Stokes, and Katie Simmons. 2016. "Europeans Fear Wave of Refugees Will Mean More Terrorism, Fewer Jobs: Sharp Ideological Divides across EU on Views about Minorities, Diversity and National Identity." July 11. http://www.pewglobal. org/2016/07/11/europeans-fear-wave-of-refugees-will-mean-more-terrorism-fewerjobs (accessed December 21, 2019).

Współpraca. 2012. Wspótpraca droga do integracji. Zalecenia dla polityki integracyjnej Polski [Cooperation as a Way to Integration. Recommendation for the Integration Policy in Poland]. Warszawa: Ministerstwo Spraw Wewndtrznych.

Wyniki. 2012. "Wyniki Narodowego Spisu Powszechnego Ludności i Mieszkań 2011." Podstawowe informacje o sytuacji demograficzno-społecznej ludności Polski oraz zasobach mieszkaniowych [Results of a National Census of the Population and Dwellings]. Warszawa: Główny Urząd Statystyczny. https://web.archive.org/web/ 20130116214520/http://www.stat.gov.pl/cps/rde/xbcr/gus/PUBL_lu_nps2011_ wyniki_nsp2011_22032012.pdf (accessed December 1, 2019).

Zuchowicz, Katarzyna. 2015. "Polska przyjęła już ponad 80 tysięcy Czeczenów i wciąż przyjmuje następnych. Czy komuś to przeszkadza?” [Poland has received 80 thousand Chechens and still receives more. Does it bother anybody?] Na:temat, September 5. http://natemat.pl/155107,polska-przyjela-juz-blisko-90-tysiecy-uchodzcow-zczeczenii-dzis-zostala-ich-tylko-garstka-bo-nie-chcieli-u-nas-zostac (accessed December 20, 2019).

Michał Buchowski is a Professor and Head of the Department of Anthropology and Ethnology at Adam Mickiewicz University, Poznan, Poland, as well as a Professor and Chair of Comparative Central European Studies at European University Viadrina in Frankfurt/Oder and an Honorary Fellow of the Royal Anthropological Institute of Great Britain and Ireland. He authored and edited several books, most recently Purgatory: Anthropology of Postsocialist Neoliberalism (2017, in Polish), and Twilight Zone Anthropology: Voices from Poland (2019). Email: mbuch@amu.edu.pl. 